\title{
INNOVATION PERFORMANCE OF THE SLOVAK REPUBLIC AND ROMANIA
}

\author{
Milan Fil'a, Jozef Kučera
}

\begin{abstract}
Innovations play a central role of the knowledge economy (characterised by the production of goods and services with high added value) and it is also a key element of economic development and the driving force of the economic development. Countries with the most developed economies are characterised not only by more stable economy, higher standard of living but also by higher innovation performance in the comparison with other countries. However, the innovation performance (and its potential) differs significantly among the EU regions; especially we can see a great gap between the former EU members and those new ones from last decade. Slovak Republic and Romania are unfortunately still in the company of those EU member countries with low innovation performance. This situation is caused mainly by the weak support of research and development (mainly weak financial support) and inadequate support of innovation-friendly corporate environment, especially in the SMEs sector, which represents the backbone of each national economy. Not only public sector should take care about the whole $R \& D$ national investments. In developed economies, it is especially the private sector which invests into innovations the most so it is very important to support the innovation-friendly environment by the public authorities. Using statistical methods, the scientific article provides insight into the causal relationship to the development rate of the region measured in terms of GDP per capita and investments in $R \& D$ to indicate disparities in Slovakia and Romania (compared to the innovation leaders in EU/EU average) in the field of innovation performance.
\end{abstract}

Keywords: innovations, competitiveness, knowledge economy, corporate environment, SME

\section{Introduction}

For more than 50 years, since the neoclassical theory of economic growth composed by Robert Solow was introduced, researchers and economists are still trying to find an answer to question of different levels of successful economic growth and prosperity.

A search for new ways of understanding growth followed, and out of this emerged a new perspective on economic growth, which put technology and innovation, rather than capital accumulation, at the front. Increasingly, the ability 
of a poor country to catch up with the rich was seen not only - or mainly - as a reflection of its ability to generate (or attract) sufficient investments, but also of its capacity to absorb existing and generate new technologies (e.g. innovate) (Fagerberg, 2010).

At the very beginning it is necessary to explain and closely characterize the main terms. The initiator of the innovation theory is considered to be J. A, Schumpeter, who in the thirties of the $20^{\text {th }}$ century regarded innovations as a driving force of economy, according to him, innovations represent combination of factors of production influenced by enterprise activities. Those are especially fundamental changes in the field of manufacturing engineering and production technology in an organisation and in leading. He regards innovation only as the first launch of a new product, raw material, technological method in the market. $\mathrm{He}$ calls all other producers imitators (Gúčík, 2012).

One of the most popular Slovak definitions of the first term - innovation can be found in publication "Innovation and Companies" (TTSK, 2010), where innovations are defined as introducing and implementing of new or much better product (goods or services), process, new marketing method or a new organizational method in company practice, working environment of all organizational parts or in external relations.

The most acclaimed form of explaining the term innovation is at present a comprehensive definition in the Oslo manual (OSLO MANUAL, 2005), which was published in 1997 by OECD: „Technological innovations of products and processes (abr. TPP innovations) which include new products and processes based on new technologies, or significant technical improvements of already existing products and processes. TPP innovation is implemented when the product is launched to the market (product innovation) or a new process innovation is introduced (process innovation).“

This manual also defines next four basic categories of innovations:

1. Product innovation

2. Process innovation

3. Organization innovation

4. Marketing innovation

Thus, on the one hand there are innovation of products/services (and also innovation of the production processes/methods) and marketing/selling methods these are closely connected to the processes of R\&D, production and sales. On the other hand there are organization innovations which are connected to the internal company structures, values/ideas or in general, with strategic management tools.

Second important term is the innovation performance. Level of innovation performance can be expressed by comprehensive methodology, which is used by the European Commission to compare innovation performance of its member states and individual regions of the EU, while it also uses the scheme of several basic indicators, such as (Code Law no. 172/2005): 
- European Patent Office, www.epo.org

- Human resources in the area of science and technology (\% of population)

- Participation in lifelong education (age of 25-64)

- Public expenses for research and development (\% GDP)

- Company expenses for research and development (\% GDP)

- Employment in medium-tech and high-tech production (\% of overall work force)

- Employment in high-tech services (\% of overall work force)

- EPO (European Patent Office) patents (per one m. citizens)

On the following pages we will analyze a correlation between innovation performance in the public and SMEs sector and investments of those sectors into R\&D in Slovak republic and Romania. The reasons why authors have chosen only one specific indicator - investments into $R \& D$ are:

1. Prove if public sector has a real interest in increasing the level of innovation performance. Innovation performance is mentioned in many strategic documents as a leading force of economic growth and knowledge economy and logically it should be supported by investments into R\&D.

2. Prove that the amount of investments into $R \& D$ is positively correlated with a level of SSI indicator of innovation performance.

3. Prove how much is the SMEs sector (as a core part of national economic development) oriented into producing innovative goods and services with an extra value.

\section{Innovation performance and policy in the European Union}

Innovation policy of the EU is based on the support of enterprise sphere. This helps to contribute towards better industrial performance and so to support meeting broader social objectives such as industrial growth, increased employment rate and competitiveness of the industry within society and its sustainability. One of the key documents supporting growth of investments into innovations and innovative solutions is Strategy 2020, approved by the Committee in 2010. This strategic document also confirmed the Lisbon Strategic Aim to increase the investment ratio into science, research and innovation at least on the level of $3 \%$ GDP of the member countries.

At present, except Sweden and Denmark, none of the member countries fulfils the set objective of the investment ration on science, research and innovation. The investment at present reaches the EU average of 28 individual investments into innovation (science and research) which represents $2.01 \%$ of the GDP. To reach the set innovation goals the EU has proposed 10 following measures: 
1) To continue in investments into innovation regardless of saving measures.

2) To improve the quality of Europe and individual state internal systems of R\&D.

3) To modernize educational systems at all levels.

4) To use the EU research area for improving cooperation of innovators and researchers.

5) To simplify the approach towards European programmes.

6) To commercialize innovations - improve the links among scientists and enterprises.

7) To dispose of the barriers restricting the introduction of new ideas into market - more functions for the SMEs sector.

8) To establish European partnerships this would support and accelerate the research, development and introduction of innovations to the market.

9) To improve innovations in the public sector.

10) To support the cooperation with international partners and open up the opportunity of the EU support programmes.

For support of innovations was created a programme HORIZONT 2020, which is designed in accordance with the Europe 2020 strategy and is actually a financial instrument of the implementation of "Innovation Union", so-called flagship "The EU Strategy for the period 2010-2020 - Europe 2020". The aim is to create the conditions of global competition - the ability of the EU at the highest level, economic growth and the creation of new jobs (Šandor, 2014).

Another programme to support innovations and to improve competitiveness of the EU is the COSME programme. This specific programme is primarily focused on the competitiveness of small and medium-sized enterprises for the period 2014-2020 and is closely connected to the programme HORIZONT 2020 (European Commnision, 2015).

From the latest available surveys and calculations published in 2014, we can conclude that the overall average innovation performance of the $\mathrm{EU}$ member states reaches a value SII at the level $\mathbf{0 . 5 5 4}$ (interval range is $0.0-1.0$ ) (graph 1). From the medium term, the EU reaches stable average innovation performance with the growth of $1.66 \%$.

Innovation performance of the Slovak Republic and Romania is in the comparison with the average of the EU member states below average and their latest level reached the value SII $\mathbf{0 . 3 2 8}$ (Slovakia) with the growth rate of $1.49 \%$ and $\mathbf{0 . 2 3 7}$ (Romania) with the growth rate of $1.90 \%$. From the medium term development point of view, we record only minor year-to-year changes in both countries. 
Graph 1: Innovation performance of individual member states of the EU in 2013 (SII)

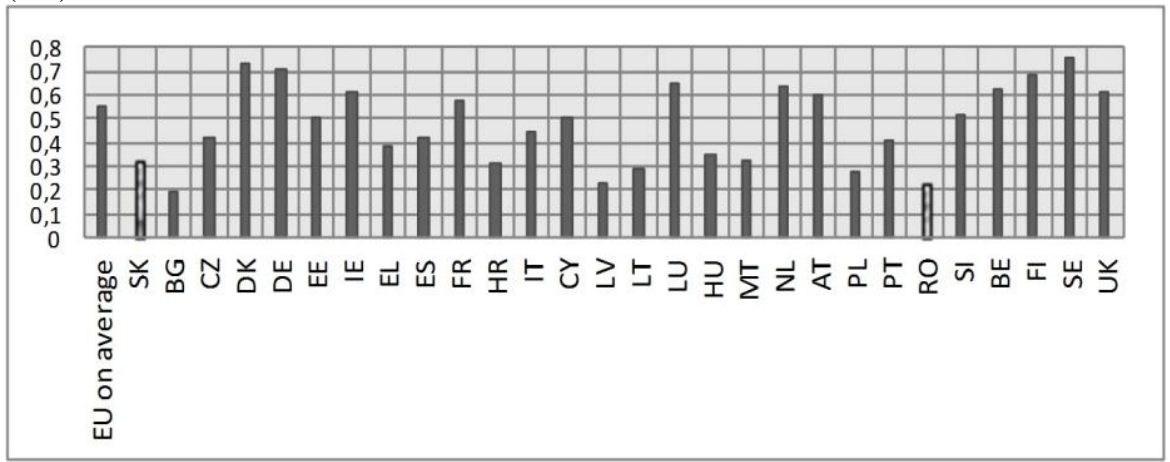

Source: European Commission, 2015

The European Commission distinguishes 4 different groups of countries according to the average performance in innovation policies:

A. Innovation leaders (SSI more than $20 \%$ above than the EU average): countries such as Denmark, Germany or Sweden

$\checkmark$ Sweden is considered to be a country with the highest long-term innovation performance among all of the EU member states. Sweden and the Nordic countries, in general, have the highest investments into research and development or innovations.

B. Innovation followers (SSI less than $20 \%$ above EU average or more than $90 \%$ of the EU average): countries such as Slovenia, France or Austria

C. Moderate innovators (SSI between 50 and $90 \%$ of the EU average): countries such as Slovakia, Hungary or Italy

D. Modest innovators (SSI less than $50 \%$ of the EU average): countries such as Romania or Bulgaria

\section{Innovation performance of the Slovak Republic and Romania}

The Ministry of Economy of the Slovak Republic in cooperation with the Ministry of Education, Science, Research and Sport of the Slovak Republic elaborated the Research and Innovation Strategy for Smart Specialization of the Slovak Republic (RIS3 SK), which was approved by the Slovak government at its meeting on 2013, November $13^{\text {th }}$ by resolution No. 665/2013. RIS3 SK represents a strategic framework document for research and innovations support in forthcoming programming period $2014-2020$ and are a basis for the creation of operational programmes (Ministerstvo školstva, vedy, výskumu a športu SR, 2013). 
There are also a few strategic documents, which are focused on the R\&D and innovation in Romania - for example The Ministry of Education and Scientific Research of Romania elaborated The National Research, Development and Innovation Strategy 2014-2020 which also should support the new programming period goals in the field of R\&D and innovation (Ministerul Educației și Cercetării Ştiinţifice, 2014).

In every single national strategic document of economic growth which is focused on the economic competitiveness improvement is mentioned a need, that a key element - R\&D must be supported by higher amount of finance. Among the investments into $R \& D$ and the innovation performance there is an explicit correlation and therefore a higher $\%$ of costs into R\&D that logically increases also the innovation performance of an individual country. The European Union adopted in 2010 the Europe 2020 Strategy, which reincorporates unfulfilled aim of the Lisbon Strategy, namely the achievement to increase investments into R\&D to a level of $3 \%$ of the EU member states GDP. This aim is fulfilled only by several Nordic countries led by Sweden, which in 2013 spent on research and development the highest amount from all EU member countries. The ratio of investments into $\mathrm{R} \& \mathrm{D} / \mathrm{innovation}$ in \% GDP within the EU (in 2013) is shown above - in map 1.

Map 1: The ratio of investments into R\&D/innovation in \% GDP within the EU in 2014

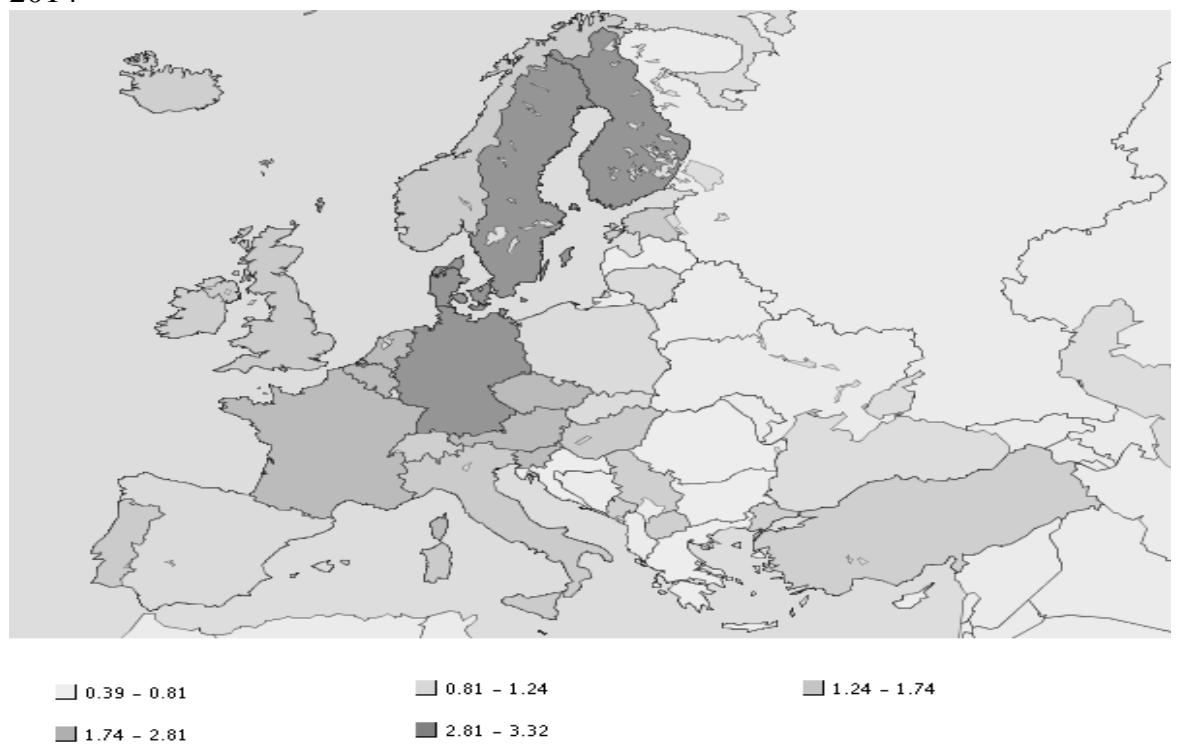

Source: EUROSTAT, 2015 
The higher investments into research and development (\% of GDP), the higher innovation performance of a country

At the same time \% ratio of GDP investments also indicates country's real interest in the development of science and research and, subsequently, in the knowledge economy. A typical example to prove that theory is Sweden which in long term spends on research and development in the comparison with the GDP the biggest amount of financial means and so it represents the leader in innovation performance among the EU member states.

The graph 2 shows an interesting comparison of science and research financing by enterprise sphere in the Slovak Republic (in 2014 it was 0,56\% GDP by public sector and $\mathbf{0 , 3 3 \%}$ by business sector) and Romania (in 2014 it was $0,22 \%$ GDP by public sector and $0,16 \%$ by business sector), which is dominated by the financing from public resources. In most EU countries, private resources are dominant compared to state resources. In the case of the Sweden, public resources take part in the financing of the given field with the ratio of 1.04 \% GDP in 2014 and business sphere up to $\mathbf{2 . 1 2} \%$.

Graph 2: Investments into science and research in the Slovak Republic, Romania and Sweden

\begin{tabular}{|c|c|c|c|c|c|c|c|c|c|c|c|c|}
\hline \multirow{5}{*}{$\begin{array}{r}3 \\
2,5 \\
2 \\
1,5 \\
1 \\
0,5 \\
0\end{array}$} & \multicolumn{12}{|c|}{ 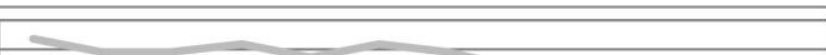 } \\
\hline & \multicolumn{12}{|c|}{2} \\
\hline & & & & & & & & & & & & \\
\hline & \multicolumn{12}{|c|}{$\bar{\Omega}$} \\
\hline & 2003 & 2004 & 2005 & 2006 & 2007 & 2008 & 2009 & 2010 & 2011 & 2012 & 2013 & 2014 \\
\hline public sector SK & 0,25 & 0,25 & 0,25 & 0,27 & 0,27 & 0,26 & 0,28 & 0,36 & 0,41 & 0,48 & 0,44 & 0,56 \\
\hline business sector SK & 0,31 & 0,25 & 0,25 & 0,21 & 0,18 & 0,2 & 0,2 & 0,26 & 0,25 & 0,34 & 0,38 & 0,33 \\
\hline public sector RO & 0,16 & 0,17 & 0,2 & 0,23 & 0,31 & 0,39 & 0,27 & 0,28 & 0,31 & 0,3 & 0,27 & 0,22 \\
\hline business sector RO & 0,22 & 0,21 & 0,2 & 0,22 & 0,22 & 0,17 & 0,19 & 0,17 & 0,18 & 0,19 & 0,12 & 0,16 \\
\hline public sector SW & 0,92 & 0,89 & 0,92 & 0,88 & 0,87 & 0,9 & 1 & 1,01 & 0,99 & 1,05 & 1,02 & 1,04 \\
\hline business sector $\mathrm{SW}$ & 2,69 & 2,49 & 2,47 & 2,61 & 2,38 & 2,59 & 2,45 & 2,21 & 2,24 & 2,22 & 2,28 & 2,12 \\
\hline
\end{tabular}

Source: EUROSTAT, 2015

In the Slovak Republic and also in Romania, financing of innovations is dominated by public resources. This indicates for example:

$>$ that the transformation to the knowledge economy will be by 2020 (determined as a deadline year for transformation in many strategic documents in Slovakia) very difficult task to achieve as it is the enterprise sphere and its research intensity (directly linked to the 
education system) that are relevant indicators of the knowledge economy development in the given country;

$>$ that our industries are focused on the fields with lower added value (e.g. assemblage in automotive industry or electrical engineering industry);

$>$ that the significant part of GDP is created by limited number of multinational enterprises, which keep their know-how and so-called $R \& D$ centres in their parent companies and subsidiaries serve solely to production purposes with adopted technology. It is consequently reflected into the overall investments of the private sector into innovations. This is an example of the automotive industry in Slovakia.

Comparing the amount of investment into $R \& D$ with the innovation performance level, we can see a positive correlation between these 2 indicators. We have already mentioned that the higher amount of investments into research and development (\% of GDP), leads to the higher innovation performance of a country and this was proved by the given example of $3 \mathrm{EU}$ countries. It was also proved that the statement (mentioned in many strategic documents in Slovakia and Romania) about the necessity of R\&D improvement as a key element of country's competitiveness, was only a goal without any remarkable financial support. Definitely, it will be very difficult to change into the knowledge economy and also to narrow the gap in living standards (compared with former EU countries) in the next decade for both our countries.

Innovation performance of the Slovak and Romanian enterprises, specially focused on the SMEs sector

Small and medium-sized enterprises form the basis of the added value creation, employment and have a considerable influence on the creation of public resources by means of tax system of individual EU member states. Their innovation performance and potential frequently and significantly determine the future direction of the whole national economy and decide on the orientation of the whole economy.

In the EU we observe the existence of the countries which are focusing only on the activities with lower added value and the existence of countries focusing strongly on the knowledge economy. Disparities between individual member states of the EU are notable. The graph 3 shows the ratio of the SMEs, which came in 2014 with innovations in the field of products / processes or organizational / marketing innovations.

It is evident from the graph 3, that the Slovak and Romanian SMEs lag behind the $\mathrm{EU}$ average and the biggest difference can be seen when compared with Sweden - leader in innovations. The overall level of Slovak enterprises innovation performance including SME category lies in the existence of several 
structural problems of the Slovak economy, policy and national legislation. The main reasons of the situation are:

$>$ insufficient support of SMEs activities in general,

$>$ absence of regional innovation centres,

$>$ absence of high-tech incubators for SMEs,

$>$ heavy bureaucratic burden of SMEs activities,

$>$ lack of qualified work force, whose education would reflect actual market needs,

$>$ insufficient support of applied research and development from the state and public administration prospective,

$>$ insufficient cooperation of enterprises and public research and educational institutions (e.g. universities, vocational schools etc.),

$>$ difficult access to the EU resources which are allocated for the support of science, research and innovations,

$>$ efforts of the Slovak government to transfer money from the resources intended for the support of science, education, employment to other projects,

$>$ insufficient government and regional support for fulfilling the Slovak and the EU innovation policy in Slovak conditions,

$>$ absent strategic concept of change from manufacturing economy to knowledge economy.

Graph 3: SMEs launching new innovations in 2014

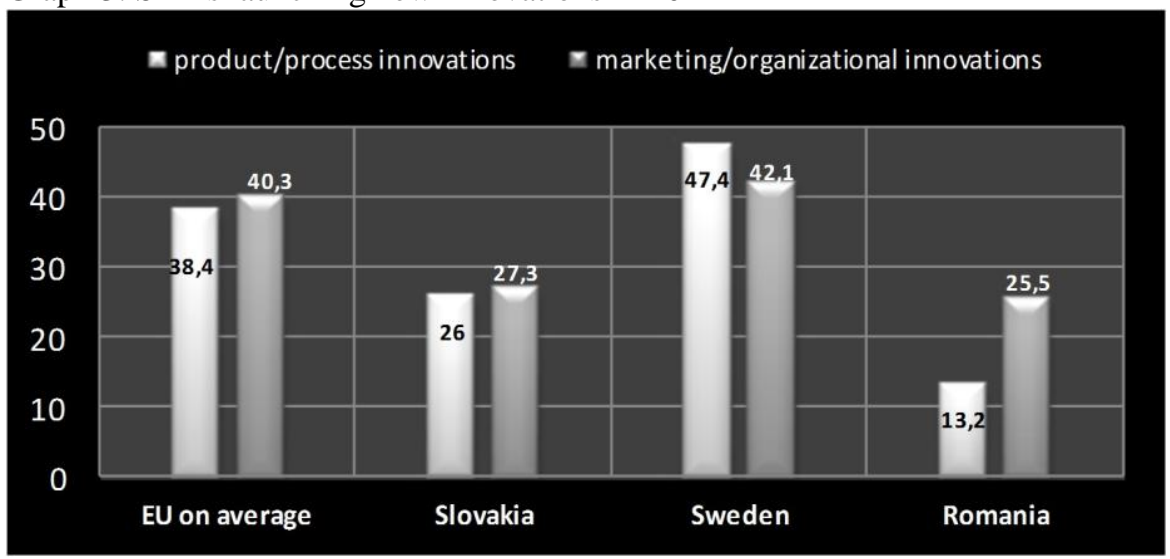

Source: European Commission, 2014

Without a closer knowledge of the environment of Romanian SMEs is quite difficult to indicate the main problems. On the other hand we could name some same reasons which probably led to bad results in the area of innovation 
performance (based on the gathered data from Eurostat and European Commission - see fig. 1 - fig. 4):

$>$ insufficient support of applied research and development from the state and public administration prospective,

$>$ insufficient cooperation of enterprises and public research and educational institutions (e.g. universities, vocational schools etc.),

$>$ insufficient government and regional support for fulfilling the Slovak and the EU innovation policy in Slovak conditions,

$>$ insufficient support of SMEs activities in general.

In the Slovak Republic do not currently exist any support instruments for the development of innovations targeted at the SME sector. To support innovations and their development in the enterprise sector is possible by two means of stimulation - financial and non-financial instruments. Financial instruments include especially the acquirement of subsidies for research and developments projects (financed for example through the EU structural funds) or possible tax relief for enterprises, which invest into science and research. Non-financial instruments include especially the creation of such corporate environment, which will enable and simplify the implementation of innovations (e.g. reduction of the bureaucratic burden when applying for incentives).

To improve the innovation performance of the Slovak and also Romanian SMEs, it would be helpful to create a coherent strategic concept (with useful and effective instruments) aiming at the implementation of innovations along with the apparatus of legislative measures, which would enable the fulfilment of the given aims.

Within financial incentives would be appropriate:

$>$ To support the creation or to create a set of credit instruments, which will be specially designed to support innovation in the SME sector

- for example: lower interest rates for $\mathrm{R} \& \mathrm{D}$ projects

$>$ To provide tax benefits and advantages for businesses, which will actively cooperate with secondary schools or universities in the creation of innovation solutions

- tax benefits (as a possible way how to support SMEs) are also mentioned in the Act No. 185/2009 Coll.

Within non-financial support would be appropriate:

$>$ To render more effective the absorption of structural funds, which are allocated for the enterprise sector.

- for example: by creating the permanent teams of professionals to deal with this issue only

To minimize the bureaucratic burden and process when absorbing financial incentives for SMEs. 
- for example: by creating the local support centres for SMEs/or by simplifying the sets of various application forms

To support the creation of high-tech clusters and incubators/innovation centres.

\section{Conclusion}

Globally it can be stated that the situation of the innovation support policy in public as well as in private sector is more than alarming. In the long term, the Slovak Republic and Romania don't only lag behind the average of the EU-27, but also behind several neighbouring countries. This intensifies its vulnerability in the field of the competitiveness preservation of our economies in harsh competitive environment of Europe.

There are many ways how to support innovation performance in the SME sector and it would be also relevant to take inspiration from the models of the leaders in innovations such as the Nordic countries. To reverse the current overall negative situation will be possible only if the research, development and innovations would become real (in legislation and expenses) state priority, its governments and the authorities of the Slovak Republic or Romania. Both of our countries have a high potential to succeed in many areas of technical and technological progress as it has quality human capital, good, interesting foreign and mainly domestic investors. By creating appropriate conditions and instruments for promoting innovations in the combination with continuous and more developed support of interlinking between enterprises, research and development institutions as well as educational institutions, there is possible a great chance of success.

\section{Acknowledgement}

This paper was prepared in the $R \& D$ cooperation of Electronic Cluster - Western Slovakia.

\section{References}

CODE LAW no.172/2005 Z.z. o organizácii štátnej podpory výskumu a vývoja a o doplnení zákona Code Law no. 575/2001 Z.z. o organizácii činnosti vlády a organizácii ústrednej štátnej správy v znení neskorších predpisov.

CODE LAW no. 185/2009 Z.z. o stimuloch pre výskum a vývoj.

EUROPEAN COMMISSION. 2014. Innovation Union Scoreboard 2014. 94 p. ISBN 978-92-79-34662-0.

EUROPEAN COMMISION. 2015. What is Cosme?. [cit. 2015-05-15]. Available at: http://ec.europa.eu/enterprise/initiatives/cosme/index_en.htm.

EUROPEAN PATENT OFFICE. http://www.epo.org. 
EUROSTAT. 2015. Eurostat Database. Available at: http://epp.eurostat.ec.europa. eu.

FAGERBERG, J. 2010. The changing global economic landscape: the factors that matter, In Robert M Solow \& Jean-Philippe Touffut (ed.), The Shape of the Division of Labour: Nations, Industries and Households. Edward Elgar, 2010.

GÚČÍK, M. 2012. Podstata a ciele inovácií. In Economic Review of Tourism. ISSN 0139-8660, 2012, vol. 45, no. 2, pp. 69.

MINISTERSTVO ŠKOLSTVA, VEDY, VÝSKUMU A ŠPORTU SR MINISTERSTVO HOSPODÁRSTVA SR. 2013. Poznatkami $k$ prosperite Stratégia výskumu a inovácií pre inteligentnú špecializáciu Slovenskej republiky. Schválená vládou SR dňa 13. novembra 2013 uznesením vlády SR č. 28588/2013.

MINISTERUL EDUCAȚIEI ȘI CERCETĂRII ȘTIINȚIFICE. 2014. Strategia Naţională de Cercetare, Dezvoltare şi Inovare 2014-2020, available: http://www.edu.ro/index.php/pressrel/22258.

OSLO MANUAL. 2005. Guidelines for Collecting and Interpreting Innovation Data. [Cit. 2015-05-10]. Available at: http://www.keepeek.com/Digital-AssetManagement/oecd/science-and-technology/oslo-manual_9789264013100-en\# page 52.

ŠANDOR, D. 2014. HORIZON 2020. [cit. 2015-03-07]. Available at: http://www.een.sk/?services_17/1028.

TTSK. 2010. „Innovation and Companies“. Publikácia vydaná v rámci projektu Duo**Stars, 2010.

\section{Ing. Milan Fil'a, PhD.}

Constantine the Philosopher University in Nitra

Trieda A. Hlinku 1, 94974 Nitra

E-mail: mfila@ukf.sk

\section{Ing. Jozef Kučera, MSc.}

Ministry of Education, Science, Research and Sport of the Slovak Republic

Stromová 1, 81330 Bratislava

E-mail: jozef.kucera@minedu.sk 